\title{
Lumber Yield of Four Native Forest Species of the Amazon Region
}

\author{
Rafael Rodolfo de Melo ${ }^{1}$ (D), Jessyca Mayra Fruett Dacroce ${ }^{2}$ (D), \\ Francisco Rodolfo Junior ${ }^{3}$ (D), Gerson dos Santos Lisboa ${ }^{4}$ (D), \\ Luciano Cavalcante de Jesus França ${ }^{5}$ (D) \\ ${ }^{1}$ Universidade Federal Rural do Semi-Árido - UFERSA, Mossoró/RN, Brasil \\ ${ }^{2}$ Universidade Federal de Mato Grosso - UFMT, Sinop/MT, Brasil \\ ${ }^{3}$ Universidade Federal do Piauí - UFPI, Bom Jesus/PI, Brasil \\ ${ }^{4}$ Universidade Federal dos Vales do Jequitinhonha e Mucuri - UFVJM, Diamantina/MG, Brasil \\ ${ }^{5}$ Universidade Federal do Sul da Bahia - UFSB, Itabuna/BA, Brasil
}

\begin{abstract}
The objective of this study was to evaluate the volumetric lumber yield of four native species of the Amazon Region: Cedrinho (Erisma uncinatum Warm), Cumaru (Dipteryx odorata Aublet), Garapeira (Apuleia leiocarpa Voguel), and Cambará (Qualea paraensis Ducke). Twelve logs of each species with different diameters were randomly selected from different sawmills in northern Mato Grosso state, Brazil. Additionally, the influence of diameter on the yield of each species was evaluated through regression analysis. Among the evaluated species, Cedrinho obtained the highest yield values, followed by Garapeira. Cumaru and Cambará showed the lowest yields, and did not differ statistically. Log diameter negatively influenced lumber yield, except for Cumaru wood, which did not present a clear relation between these parameters.
\end{abstract}

Keywords: diameter, sawmills, tropical wood. 


\section{INTRODUCTION}

Wood has always been considered very useful for the development of humankind, both for its intrinsic and commercial uses. The forestry sector is significant in the Brazilian economy, accounting for 3.4\% of the Country's Gross Domestic Product (GDP), generating approximately 44.6 billion dollars. The Amazon region stands out as one of the main producers of tropical wood worldwide, and the north region of Mato Grosso state is highlighted in forest production (Melo et al., 2015).

The forestry sector is very important for the economy of Mato Grosso state, including 228 approved Sustainable Forest Management Plans (PMFS - Planos de Manejos Florestais Sustentáveis), with a total area of $243,925.58$ ha that produces 85,659 tons of lumber, generating approximate revenue of USD86.024 million for the international market and BRL39 million for the domestic market (Centro das Indústrias Produtoras e Exportadoras de Madeirado no Estado de Mato Grosso - CIPEM, 2014).

In the state of Mato Grosso, mainly in its North region, there is a great concentration of sawmills that use species native to the Amazon, which, in turn, are responsible for boosting the regional commerce. Woods with the highest added value are preferentially extracted, with civil construction as the main destination. Wood felled and harvested in the interior of the state is destined for both the domestic and external markets.

This great lumber potential brings many benefits to the region. However, due to technological problems or lack of knowledge about the raw material, one of the major impediments in the sector is associated with inefficient utilization, increasing the cost of the final product and resulting in large waste production (Rocha, 2007).

The process of transforming a circular log section into rectangular and/or square pieces is called timber conversion system. There are several timber conversion systems that can be adapted to the most diverse needs, varieties of species, and log shapes (Murara et al., 2013). In northern Mato Grosso state, the conventional method for transforming raw material is still in use, in which the logs are sawn without prior classification and exact definition of a cut model, because the operator determines how the cuts will be performed. This method often induces low utilization efficiency of the log, generates a larger volume of by-products, and increases the cost of the final product.

The yield of each log is influenced by the type of saw used - the thicker the saw, the higher the waste percentage, thus reducing yield; by skilled labor, which is important in decision-making because it is the worker who decides the length to be cut in case of defects, thereby making the best use of the wood; by the characteristics of each species, considering that some species are more susceptible to attack by organisms such as rot, insects, and xylophages; and by dendrometric variables such as the diameter and tapering of the trunk, which directly influence yield and waste generation (Rocha, 2007)

Therefore, it is necessary to gather technical information regarding the yield of sawn timber as well as on waste generation, so that native wood processed in the region can be better used, thereby generating greater profitability for the state. The objective of the present study was to analyze the timber conversion yield of four native species of the Amazon Biome located in the north region of Mato Grosso state.

\section{MATERIAL AND METHODS}

\subsection{Study site}

This study was conducted in three different sawmills located in the municipalities of Sinop, Sorriso, and Tabaporão in northern Mato Grosso state, Brazil. The sawmills assessed were small, with average production capacity of $500 \mathrm{~m}^{3} / \mathrm{month}$. The main activity developed by the industry is the conversion of logs into raw sawn timber. The raw wood is processed to produce boards and beams, among other wood pieces. Processed pieces such as lining, decks, slats, and rafters, flattened or not, are also produced. All sawmills used species native to the Amazon for wood processing, acquired from suppliers with forest management plans approved by the competent environmental agency.

\subsection{Machinery}

The sawmills where the information was collected have similar and good-quality machines to process tropical wood in the region, consisting mainly of the following equipment: vertical band saw (main sawing), circular table saw (alignment), and pendulum circular 
saw (trimmer). The main characteristics of this equipment are i) Vertical band saw set: $17.8 \mathrm{~cm}$ blade width, $110 \mathrm{~cm}$ diameter wheel, $75 \mathrm{w}$ WEG main motor power, $7.5 \mathrm{hp} \mathrm{WEG} \mathrm{auxiliary} \mathrm{motor} \mathrm{power} \mathrm{(winch),}$ and $15 \mathrm{cv}$ WEG feed motor power; ii) Circular table saw set: $350 \mathrm{~mm}$ saw diameter, $4.0 \mathrm{~mm}$ cutting teeth thickness, and $25 \mathrm{cc}$ WEG motor power; iii) Pendulum circular saw: $350 \mathrm{~mm}$ saw diameter, $4.0 \mathrm{~mm}$ cutting teeth thickness, and $25 \mathrm{cc}$ WEG motor power.

\subsection{Sampling}

Four logs were selected in each of the sawmills for each of the different species under study: Cedrinho (Erisma uncinatum), Cumaru (Dipteryx odorata), Garapeira (Apuleia leiocarpa), and Cambará (Qualea paraensis), totaling $12 \mathrm{logs} /$ species. In total, 48 logs were evaluated. Each $\log$ was duly identified prior to undergoing the sawing process. After that, the Smalian method was applied to obtain the volume of the selected logs (Campos \& Leite, 2009).

\subsection{Determining lumber yield}

Volumetric yield of sawn timber (also known as utilization percentage) corresponds to the ratio between the volume of lumber produced and the volume of logs before sawing, expressed as a percentage (Equation 1). This parameter was calculated based on the ratio between the volume of sawn wood obtained from each log and the log volume calculated by the Smalian method.

$R=\frac{V_{M}}{V_{T}} \times 100$

Where: $R=$ lumber yield in $\%$; $V_{M}=$ volume of lumber in $\mathrm{m}^{3} ; V_{T}=$ volume of logs in $\mathrm{m}^{3}$.

\subsection{Estimating waste volume}

The waste generated was classified into slabs and top cuts, band-saw sawdust, circular-saw sawdust, and bark. The waste volume generated by wood processing using band saws was calculated by measuring the sawdust volume produced. The same technique was used to estimate the waste produced by circular saws. These data were obtained by an estimation of three logs for each of the evaluated species.
Bark losses were also estimated by measuring the thickness of the bark using Equation 2. Solid volume of the slabs and top cut waste were determined by the difference between the total volume of each log and the other estimated parameters (Equation 3). All these values were subsequently converted into percentages.

$V_{C}=V_{T}-\left(\frac{\pi \times D s c^{2}}{40000} \times L\right)$

$V_{R}=V_{T}-\left(V_{M}+V_{C}+V_{S}\right)$

Where: $V_{C}=$ volume of bark in $\mathrm{m}^{3} ; V_{T}=$ volume of logs with bark in $\mathrm{m}^{3} ; D_{S C}=$ average diameter of barkless logs in $\mathrm{cm} ; L=\log$ length in $\mathrm{m} ; V_{R}=$ volume of slabs and top cuts in $\mathrm{m}^{3} ; V_{M}=$ volume of lumber in $\mathrm{m}^{3}$; $V_{s}=$ volume of sawdust in $\mathrm{m}^{3}$.

\subsection{Analysis of the results}

Yield results were evaluated through descriptive statistics considering the minimum, mean, maximum, standard deviation, and coefficient of variation values for each of the analyzed variables per species. Analysis of variance (ANOVA) and the Tukey's test at 95\% probability were conducted for the parameters detected with significance by the $F$-test. The relationship between yield and $\log$ diameter was assessed by regression analysis.

\section{RESULTS AND DISCUSSION}

\subsection{Lumber yield}

Descriptive statistics of lumber yields for the evaluated tropical species are presented in Table 1. Cedrinho wood had an average yield of $57.27 \%$, with minimum and maximum values ranging between 45.82 and $65.38 \%$, respectively. As for Cumaru wood, an average yield of $47.13 \%$ was found. This seemingly low average occurred because three logs were hollow due to xylophage attacks. This effect can be observed in the minimum yield value (37.50\%), which was a consequence of wood loss resulting from the xylophage attack. This characteristic is indicative that trees of this species present susceptibility to this type of attack. However, it was possible to obtain a maximum yield of $68.25 \%$ for the same species for a log with low conicity and no defects. According to an economic feasibility study conducted by Oliveira et al. (2003) in 
Table 1. Descriptive statistics for the wood yield of Cedrinho (Erisma uncinatum), Cumaru (Dipteryx odorata), Garapeira (Apuleia leiocarpa) and Cambará (Qualea paraensis) species.

\begin{tabular}{ccccc} 
Values & \multicolumn{4}{c|}{ Yield (\%) } \\
\cline { 2 - 5 } & Cedrinho & Cumaru & Garapeira & Cambará \\
Minimum & 45.82 & 37.50 & 43.83 & 41.12 \\
Mean & 57.27 & 47.13 & 52.50 & 47.28 \\
Maximum & 65.38 & 68.25 & 77.57 & 62.16 \\
SD & 6.65 & 8.59 & 9.56 & 6.42 \\
\hline CV $(\%)$ & 11.62 & 18.23 & 18.21 & 13.58 \\
\hline
\end{tabular}

SD: standard deviation; CV: coefficient of variation.

three sawmills in the municipality of Jaru, the average yield found for Cumaru wood ranged from 55 to $67 \%$. The explanation for the difference in yield found in this study is the xylophage attack in some samples.

In the case of Garapeira, the yield observed for the logs of this wood ranged from 43.8 to $77.57 \%$, with a mean of $52.50 \%$. As for the Cambará wood, the yield found varied between 41.12 and $62.16 \%$, with a mean of $47.28 \%$. These results are similar to those reported by Garcia (2013), when analyzing the operational yield of a sawmill using Cambará (Qualea albiflora Warm.) species in the Amazon region, and obtained an average yield value of $48.90 \%$. In contrast, when analyzing the influence of different cutting heights on the quality, productivity, and yield of Qualea sp. sawn wood in the northern region of Mato Grosso state, Botin (2011) found an average yield value of $60.49 \%$. These yield values are superior to those observed in the present study.

Analysis of variance showed significant difference between the average yield values between the studied forest species (Figure 1). Cedrinho followed by Garapeira were the species that obtained the highest yield values, whereas Cumaru and Cambará did not differ statistically, and obtained the lowest yield values. According to Rocha (2007) and Vital (2008), yield between 45 and 55\% is considered normal for hardwoods. This percentage varies depending on the quality of the stands/forest, the equipment and sawing methods employed, and the professional qualification of the workers (Nogueira, 2007). Thus, it was verified that the Cumaru, Garapeira and Cambará species showed yield values within the standards for hardwood species, whereas the yield for Cedrinho wood was considered high.

According to Murara et al. (2013), among the main factors that can significantly affect the volumetric yield of sawn wood, the following can be highlighted: $\log$

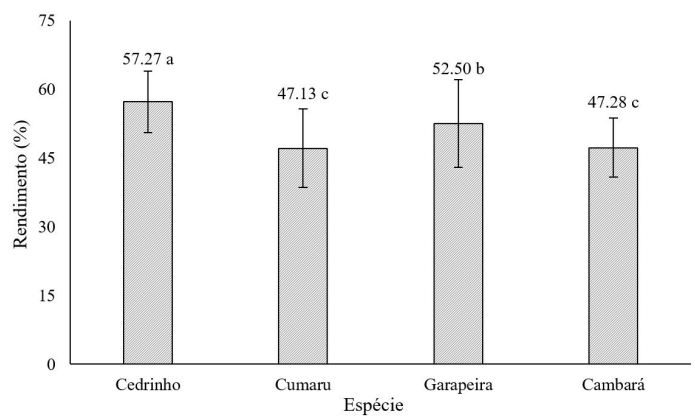

Figure 1. Comparisons between lumber yield averages observed for Cedrinho (Erisma uncinatum), Cumaru (Dipteryx odorata), Garapeira (Apuleia leiocarpa), and Cambará (Qualea paraensis) wood. Means followed by the same letter do not differ significantly by the Tukey's test at $5 \%$ probability.

quality; implemented sawing techniques; equipment operation, and log diameters. Of these, log quality is preponderant, being able to influence up to $70 \%$ of the success in obtaining high yield values. Thus, it is believed that log quality was a determining factor for the trends observed in the present study. Therefore, it can be stated that the Cedrinho species shows better shape and quality compared with those of Cumaru for obtaining lumber.

\subsection{Losses during the sawing process}

Table 2 presents a comparison between the waste volumes generated during the sawing process for the different evaluated species. Among the types of waste evaluated, the one originating from the main sawing produced by the band saws was the only one that showed no statistically significant difference, with similar proportions regardless of the species analyzed. Regarding the waste produced by the circular saws, the lowest percentages were observed for Cedrinho 
Table 2. Comparisons between the average wastes generated in wood processing according to the different studied species: Cedrinho (Erisma uncinatum), Cumaru (Dipteryx odorata), Garapeira (Apuleia leiocarpa), and Cambará (Qualea paraensis).

\begin{tabular}{|c|c|c|c|c|}
\hline \multirow{3}{*}{ Species } & \multicolumn{4}{|c|}{ 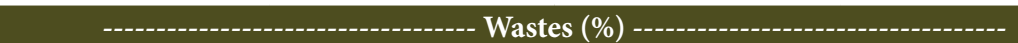 } \\
\hline & \multirow{2}{*}{ Slabs and top cuts } & Sawdust & Sawdust & \multirow{2}{*}{ Bark } \\
\hline & & (band saw) & (circular saw) & \\
\hline Cedrinho & $21.84 \mathrm{~b}$ & $15.98 \mathrm{a}$ & $4.48 \mathrm{~b}$ & $0.42 \mathrm{~b}$ \\
\hline Cumaru & $28.81 \mathrm{a}$ & $16.24 \mathrm{a}$ & $7.38 \mathrm{a}$ & $0.44 \mathrm{~b}$ \\
\hline Garapeira & $26.80 \mathrm{ab}$ & $13.43 \mathrm{a}$ & $6.76 \mathrm{a}$ & $0.52 \mathrm{~b}$ \\
\hline Cambará & $29.20 \mathrm{a}$ & $15.67 \mathrm{a}$ & $7.02 \mathrm{a}$ & $0.83 \mathrm{a}$ \\
\hline
\end{tabular}

Means followed by the same letter in the column, do not differ significantly by the Tukey's test at $5 \%$ probability.

wood. No statistically significant differences were found between the other species.

Waste generated from wood processing into slabs and top cuts was higher for Cumaru and Cambará, whereas lower values were observed for Cedrinho and Garapeira, species that also obtained the highest yield percentages. According to Murara et al. (2013), careful control of the raw material quality prior to processing is of great importance. Avoiding logs with greater potential to generate waste enables substantial improvements in the economy and operational performance of the sawmill. The implementation of a standard inspection system based on the application of classification rules that reject or penalize defective logs is a good alternative to waste generation control.

The highest volume of bark losses was recorded for Cambará wood. It is worth noting that the value found $(<1 \%)$ can be considered low, even for this species. Such results are common for Amazon species, because wood processing of these species is usually conducted with individuals of large diameters. In the present study, the evaluated diameters varied between 40 and $120 \mathrm{~cm}$. According to Miranda et al. (2002), the low volume of bark loss is a positive aspect of the wood sawing process, considering that a large amount of bark can lead to higher costs for the companies resulting mainly from the need for debarking and waste accumulation.

According to Fontes (1994), the largest amount of waste is generated by primary and secondary processing of logs. Considering the waste generated by the production process, such as bark, slabs, refills, shavings and sawdust, it would be irrational not to promote the maximum use of these by-products from primary wood processing. Such waste is initially regarded as discards of the process; however, they can safely leave the sawmill as raw material for the production of pulp, cellulose, wood sheets, and organic compounds, in addition to providing energy self-sufficiency for the sawmill itself.

\subsection{Influence of diameter on yield}

Analysis of the relationship between yield and diameter of Cedrinho wood (Figure 2) showed that the volumetric yield gradually decreases as the mean diameter increases. According to Biasi \& Rocha (2007), Cedrinho logs between 60 and $70 \mathrm{~cm}$ of diameter present lower yields compared with those of logs of smaller diameters. This decrease in lumber yield occurred because the thicker logs had an incidence of internal faults, such as cracks, insect attacks, rot, etc.

Mean diameter did not directly influence the Cumaru wood yield. The yield values remained very close even for logs with larger average diameter. These values are in agreement with those reported in a study conducted by Murara et al. (2013) with Pine lumber, where diameter classes 2 (0.241-0.280 m), $3(0.281-0.340 \mathrm{~m}), 4(0.341-0.38 \mathrm{~m})$, and $5(0.381-0.44 \mathrm{~m})$ showed very close average yield results, and which can be explained by sawing without log classification and a specific model for each of the logs. Thus, log utilization becomes inadequate, resulting in an unsatisfactory yield. Another factor that should be considered is the variety of products obtained from the logs (planks, beams, boards, laths/slats, rafters, fillets/battens, etc.), which depending on the diameter classes may not be suitable for obtaining products of larger dimensions. In the study conducted by Biasi \& Rocha (2007), Itaúba species (M. itauba) showed a reduced yield class, leading to reduced use of the 

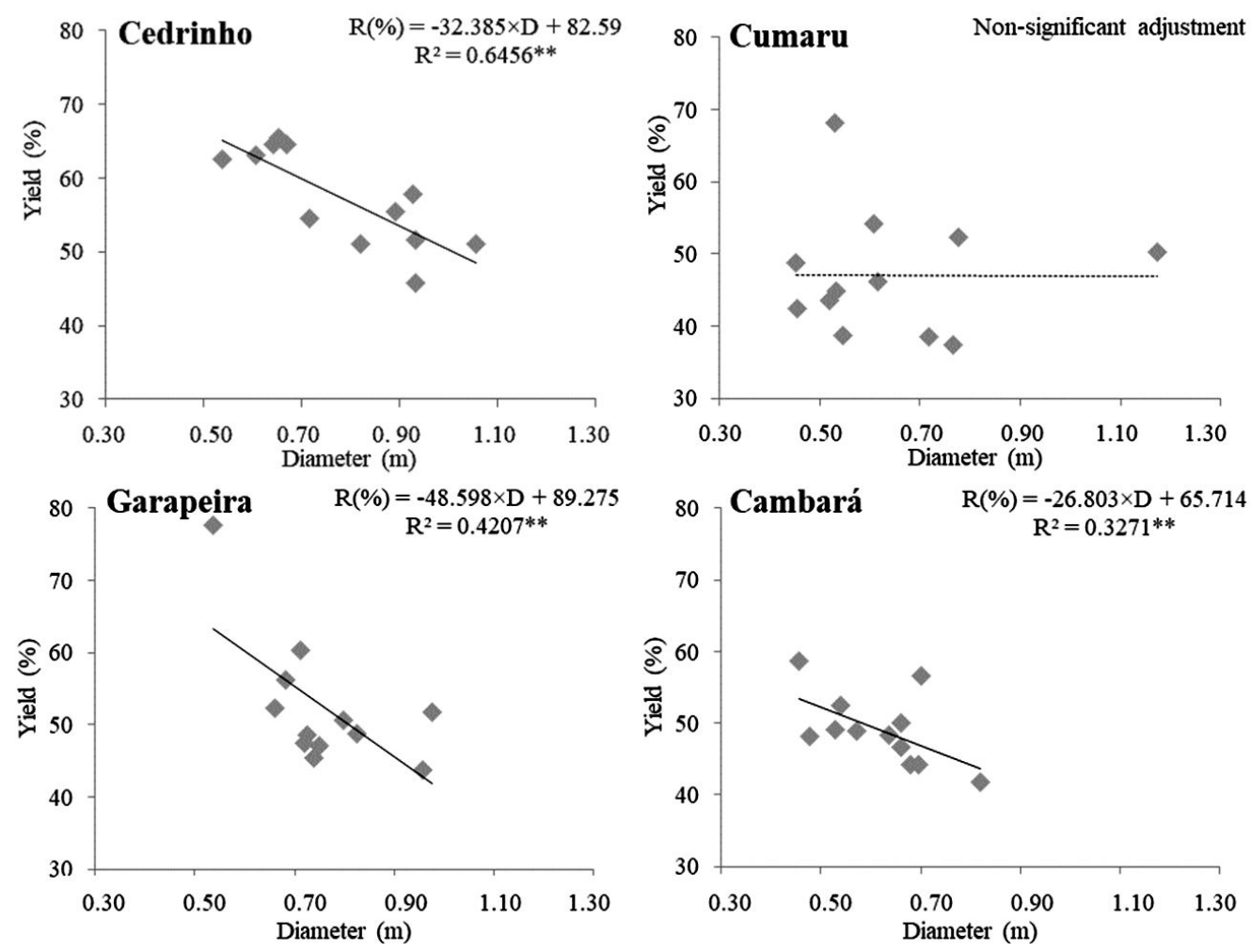

Figure 2. Regression analysis evaluating yield variation in relation to diameter for Cedrinho (Erisma uncinatum), Cumaru (Dipteryx odorata), Garapeira (Apuleia leiocarpa), and Cambará (Qualea paraensis) wood. ${ }^{* *}$ Significant at $1 \%(\mathrm{p} \backslash 0.01)$.

logs and generating greater wood loss in the form of waste because some of the logs presented defects such as cracks, rot, and hollows.

As observed for Cedrinho, wood from the Garapeira and Cambará species also showed yield values that gradually decreased as log diameter increased. According to the study by Rocha (2000), it is normal for logs of reforestation wood with smaller diameters to have lower yield values. However, when comparing the yield of sawn lumber of two diameter classes (19-25 and 25-30 cm), it was observed that the smaller diameter logs showed higher yields.

\section{CONCLUSIONS}

Among the studied species, Cedrinho (Erisma uncinatum) followed by Garapeira (Apuleia leiocarpa) wood showed the highest volumetric yield of sawn wood. The diameters of Cedrinho, Garapeira, and Cambará wood significantly influenced the lumber yield. Thus, increased log diameter reduces the lumber yield for these species.

\section{SUBMISSION STATUS}

Received: 14 jun., 2016

Accepted: 16 nov., 2017

\section{CORRESPONDENCE TO}

\section{Rafael Rodolfo de Melo}

Departamento de Ciências Agronômicas e Florestais, Universidade Federal do Semi-Árido UFERSA, Av. Francisco Mota, 572, Bairro Costa e Silva, CEP 59625-900, Mossoró, RN, Brasil e-mail: rafael.melo@ufersa.edu.br

\section{REFERENCES}

Biasi CP, Rocha MP. Rendimento em madeira serrada e quantificação de resíduos para três espécies tropicais. Floresta 2007; 37(1): 95-108. http://dx.doi.org/10.5380/ rf.v37i1.7845.

Botin AA. Influência das diferentes alturas de corte na qualidade produtividade e rendimento da madeira serrada 
de Qualea sp. na região norte do Estado de Mato Grosso [monografia]. Sinop: Instituto de Ciências Agrárias e Ambientais, Universidade Federal de Mato Grosso; 2011.

Campos JCC, Leite HG. Mensuração florestal: perguntas e respostas. 3. ed. Viçosa: UFV; 2009.

Centro das Indústrias Produtoras e Exportadoras de Madeira do Estado de Mato Grosso - CIPEM. Base florestal de MT quer consolidar raízes e crescer ainda mais [online]. Cuiabá: CIPEM; 2014 [cited 2014 Out. 27]. Available from: http://www.cipem.org.br/conteudo. php? sid $=44 \&$ cid $=3081$ \&parent $=0$

Fontes PJP. Autossuficiência energética em serraria de Pinus e aproveitamento dos resíduos [dissertação]. Curitiba: Setor de Ciências Agrárias, Universidade Federal do Paraná; 1994.

Garcia FM. Rendimento operacional de uma serraria com a espécie cambará (Qualea albiflora Warm.) na região Amazônica [dissertação]. Botucatu: Faculdade de Ciências Agrárias, Universidade Estadual Paulista Júlio de Mesquita Filho; 2013.

Melo RR, Pastore KC, Mascarenhas ARP, Acosta FC, Pedrosa TD, Serenini L Jr. Vouchers for releasing forestry credit (CLCF) for Sinop, Mato Grosso, Brazil. Nativa 2015; 3(1): 36-43. http://dx.doi.org/10.14583/2318-7670.v03n01a06.
Miranda GM, Da Silva ML, Machado CC, Leite HG. Contribuição da casca na composição do custo de transporte da madeira de eucalipto. Revista Árvore 2002; 26(2): 145-148.

Murara MIM Jr, Rocha MP, Trugilho PF. Estimativa do rendimento em madeira serrada de pinus para duas metodologias de desdobro. Floresta e Ambiente 2013; 20(4): 556-563.

Nogueira M. Técnicas de serraria. In: Oliveira JTS, Fiedler NC, Nogueira M. Tecnologias aplicadas ao setor madeireiro. Vitória: Aquarius; 2007. p. 165-183.

Oliveira AD, Martins EP, Scolforo JRS, Rezende JLP, Souza AN. Viabilidade econômica de serrarias que processam madeira de florestas nativas - o caso do município de Jarú, estado de Rondônia. Cerne 2003; 9(1): 1-15.

Rocha MP. Eucalyptus grandis Hill ex Maiden e Eucalyptus dunnii Maiden como fontes de matéria prima para serrarias [tese]. Curitiba: Setor de Ciências Agrárias, Universidade Federal do Paraná; 2000.

Rocha MP. Técnicas de serrarias. In: Oliveira JTS, Fiedler NC, Nogueira M, organizadores. Tecnologias aplicadas ao setor madeireiro. Jerônimo Monteiro: Suprema; 2007. p. 209-270.

Vital BR. Planejamento e operação de serrarias. Viçosa: UFV; 2008. 